\title{
Positive Influence of the Multimedia in Primary Education
}

\author{
Singh Shilpa ${ }^{1 *}$, Mishra Sunita ${ }^{2}$
}

\section{ABSTRACT}

Multimedia is an integration of various type of media. In it involves text, audio, video, graphics and many more. Multimedia is a term frequently heard and discussed among educational technologists today. Multimedia items used in smart classes, video projector, projection screen etc. Multimedia play a important role of many areas of primary education children in development of verbal communication, the ability to think, the ability to understanding. The present investigation identifies the positive influence of different types of multimedia in primary education. For the investigation, various schools were selected in the five mohllas of Alambagh area in Lucknow city. These Mohall as are Pawanpuri, Kailaspuri, Geetapalli, Krishnapalli and Sujanpura. A total of 120 Pre-primary and primary teachers were selected for the study. Random sampling method was used for sample selection and questionnaire schedule was used for data collection. The t test used in research for data analysis. The results revealed that multimedia have capacity to change the child abilities in positive way, increased content related knowledge and thinking of students.

Keywords: Multimedia, Primary Education, Positive influence.

The word comes multimedia comes from the Latin word "multus" which means "numerous" \& media which means "middle" and "centre". Multimedia is a type of communication that uses that uses multiple forms of media. In multimedia, multiple means exchanges of information. An example of multimedia is PowerPoint used with a tape recording and photos.

Multimedia has important characteristics that make it different from the other forms of media-it is digital and interactive. Digital multimedia is a combination of media (text, pictures, audio and video) that is represented digitally and hence can be treated as data by computer programs. In interactive, It is clearly a field of fundamental research, social, educational and economical importance, as it combines multiple disciplines for the development of multimedia systems that are capable to sense the environment and dynamically process, edit, adjust or generate new

\footnotetext{
${ }^{1}$ M.Sc. Student, Department of Human Development \& Family Studies School for Home Sciences, Babasaheb Bhimrao Ambedkar University, Lucknow

${ }^{2}$ Professor, (Dean \& Head), Department of Human Development \& Family Studies School for Home Sciences, Babasaheb Bhimrao Ambedkar University, Lucknow

*Responding Author

(C) 2016 I S Shilpa, M Sunita; licensee IJIP. This is an Open Access Research distributed under the terms of the Creative Commons Attribution License (http://creativecommons.org/licenses/by/2.0), which permits unrestricted use, distribution, and reproduction in any Medium, provided the original work is properly cited.
} 
content. For this purpose, ideas, theories, methodologies and inventions are combined in order to form novel applications and systems.

Early childhood age is a growing independence stage of life span and child enters first grade in school. It is a age of curiosity. Early childhood education/primary education is a term that is used to commonly describe the formal teaching and care of young children by individuals or professionals other than their family or in settings outside the child's home.

\section{OBJECTIVE OF THE STUDY}

- $\quad$ To identify different types of multimedia in primary education.

- $\quad$ To study about positive influence of multimedia elements in primary education.

\section{Limitations of the Study}

- $\quad$ The study was cross- sectional one.

- In this study information was collected on self administered questionnaire. We cannot rule out information bias.

- $\quad$ The present study is limited to a sample of 120 respondents.

- $\quad$ In these study only urban areas taken that's by not allowed in rural areas.

\section{REVIEW OF LITERATURE}

Multimedia devices have quality to improve early education. Television helpful for increased knowledge about moral values in early childhood. Computers provide correct knowledge in interactive ways. Videos are mostly based on real situation that's by children's interacting easily. Animation are deeply affected the mind of children's and increased their academic performances. The presentations through slide projectors increase children's attention. (Singh,2013)

High significant role of multimedia in early childhood education for increased their content knowledge and understandings. The different types of multimedia are high significant to their academic performances.(Singh,2013)

Young children's engagement with digital texts. Current educational practices are becoming increasingly anachronistic within a world in which knowledge, learning and relationships are being re-defined in digital environments. As studies of children's home lives indicates, many young children engage in digital practices in the home and such experience needs to be recognized as a resource for their current and future meaning-making. New ways of thinking about the relationship between literacy, technology and learning in the early years are needed. (Burnett, 2010)

Educational technology such as multimedia plays a fundamental and crucial role in teaching learning process at primary level. It makes teaching learning process more effective and successful. Majority of the teachers were in the opinion that education technology ensures 
students participation, student's motivation, effective teaching, to attract student's attention, and enrichment of atmosphere for teaching learning process. It was found that teachers were not trained for the effective use of educational technology. (Suleman, 2011)

Interactive learning allows children to explore new ideas with other children and adults who are able to converse with them showing that they value what they say and that they are respected as persons. Through interactions teachers also scaffold children's learning enabling them to go to another level, as they make the children to make better, deeper and more accurate sense of their experiences. Interactions facilitate developmentally appropriate practice, as the children's group, individual and cultural needs are met. (Mishra, 2011)

\section{RESEARCH METHODOLOGY}

The study was conducted in the year 2013in Lucknow city. The main area selected for the study was Alambagh. In this area five mohllas were selected i.e. Pawanpuri, Kailaspuri, Geetapalli, Krishnapalli and Sujanpura. A total of 120 Pre-primary and primary teachers were selected for the study. Random sampling method was used for sample selection and self made questionnaire method was used for data collection. After data collection, the data were tabulated in Microsoft excel and analysis was done by using frequency, percentage and t-test through SPSS $\left(20^{\text {th }}\right.$ version).

\section{RESEARCH FINDINGS AND DISCUSSION}

Table.1- Mean, SD and f-value of multimedia and their positive influence in primary education based on language use in schools:

\begin{tabular}{|c|c|c|c|c|c|c|}
\hline \multirow[t]{2}{*}{ Questions } & \multicolumn{2}{|l|}{ Hindi } & \multicolumn{2}{|c|}{ English } & \multirow[t]{2}{*}{ t-value } & \multirow[t]{2}{*}{ Sig } \\
\hline & Mean & SD & Mean & SD & & \\
\hline $\begin{array}{l}\text { Do you know about } \\
\text { multimedia. }\end{array}$ & .82 & .383 & .85 & .363 & .453 & .502 \\
\hline $\begin{array}{l}\text { Do you know about } \\
\text { multimedia elements (text, } \\
\text { audio, video, graphics, } \\
\text { and animation). }\end{array}$ & .45 & .500 & .98 & .147 & 615.766 & $.000 * * *$ \\
\hline $\begin{array}{l}\text { Animated video makes } \\
\text { education easy. }\end{array}$ & .59 & .494 & .80 & .401 & 28.234 & $.000 * * *$ \\
\hline $\begin{array}{lr}\text { Use of graphics makes } \\
\text { education } \\
\text { interesting. }\end{array}$ & .70 & .460 & .89 & .315 & 31.885 & $.000 * * *$ \\
\hline $\begin{array}{l}\text { Educational videos based } \\
\text { on real life situations so } \\
\text { will increase children's } \\
\text { understanding. }\end{array}$ & .66 & .476 & .89 & .315 & 48.168 & $.000 * * *$ \\
\hline $\begin{array}{l}\text { Animated stories are } \\
\text { simple, clear and easy to } \\
\text { understand. }\end{array}$ & .67 & .473 & .80 & .401 & 11.578 & $.001^{* * *}$ \\
\hline
\end{tabular}




\begin{tabular}{|l|l|l|l|l|l|l|}
\hline $\begin{array}{l}\text { Using multimedia in } \\
\text { classroom is helpful for } \\
\text { interaction between } \\
\text { student and teacher. }\end{array}$ & .500 & .76 & .431 & 22.792 & $.000^{* * *}$ \\
\hline $\begin{array}{l}\text { Multimedia helps in } \\
\text { communicating to large } \\
\text { no. of students in class. }\end{array}$ & .55 & .500 & .63 & .488 & 2.819 & .096 \\
\hline $\begin{array}{l}\text { Children enjoy education } \\
\text { including multimedia } \\
\text { elements. } .42\end{array}$ & .497 & .65 & .482 & 2.556 & .113 \\
\hline $\begin{array}{l}\text { Multimedia provides } \\
\text { equal education in } \\
\text { creative way for all types } \\
\text { students. }\end{array}$ & & .403 & .87 & .341 & 85.080 & $.000^{* * *}$ \\
\hline
\end{tabular}

$\left(\mathrm{p}<0.05^{*}\right) \&\left(\mathrm{P}<0.001^{* * *}\right)$

The above table shown the high significance differences in do you know about multimedia elements (text, audio, video, graphics, animation), animated videos makes education easy, use of graphics makes education more interesting, educational videos based on real life situations so will increase children's understanding, animated stories are simple, clear and easy to understand, using multimedia in classroom is helpful for interaction between student and teacher, multimedia provides equal education in creative way for all types students. No significance differences were found in do you know about multimedia, multimedia helps in communicating to large no. of students in class and children enjoy education including multimedia elements.

\section{CONCLUSION}

The results show that most of respondents (teachers) agreed on the use of multimedia in primary education. The multimedia makes child's education clean, realistic and enjoyable. There is significant differences show in different types of multimedia elements increased knowledge of child in positive way in primary education.

\section{REFERENCES}

Burnett, C. (2010). Technology and literacy in early childhood educational settings: a review of research. Journal of early childhood literacy, 10 (3), 247-270.

Hurlock, B. E. (1981) 'Developmental psychology a life span approach', $5^{\text {th }}$ edi. TATA MCGRAW Hall publishing company Ltd.

Mishra, S. (2011). Quality dimensions of early childhood care and education concerns and issues. RIE. NCERT. Bubaneswar Odisha.15-28. www.riebbs.ori.nic

Singh, S. \& Mishra, S. (2013). A study about role of multimedia in early childhood education. International journal of humanities and social science invention. 2(6). 80-85.

Singh, S. \& Mishra, S. (2013). A study about role of multimedia in early childhood education. Lap Lambert Academic Publishing. ISBN: 978-3-659-47127-8. 1-5 
Suleman, Q. (2011). Role of educational technology at Primary School Level in district Karak (KHYBER PUKHTUNKHWA). International Journal of Academic Research in Business and Social sciences. 1(3). 85-94

\section{Website References}

Digital multimedia design program (2013), reserved from

www.digitalmultimediaprogramharoldwashingtoncollege.info/pages-animation.html [30 jan2013,10.40 pm]

Internship Questions (2015), reserved from http://internships.about.com/od/internshipsquestions/g/whatismultimedia.htm. [30 Jan 2013, 10:25 pm].

What is multimedia (2016), reserved from http://www.htcampus.com/article/what-multimedia910[30jan2013, 10:32 pm]. 